ACTA MYCOLOGICA

Vol. 48 (2): 219-225

2013
Dedicated to Professor Maria Ławrynowicz on the occasion of the 45th anniversary of her scientific activity

DOI: $10.5586 / \mathrm{am} .2013 .023$

\title{
Sistotrema luteoviride sp. nov. (Cantharellales, Basidiomycota) from Finland
}

\author{
HEIKKI KOTIRANTA ${ }^{1}$ and KARL-HENRIK LARSSON ${ }^{2}$ \\ ${ }^{1}$ Finnish Environment Institute, Natural Environment Centre, Biodiversity Unit \\ P.O. Box 140, FI-00251 Helsinki, heikki.kotiranta@ymparisto.fi \\ ${ }^{2}$ Natural History Museum, University of Oslo \\ P.O. Box 1172 Blindern, NO-0318 Oslo, k.h.larsson@nhm.uio.no
}

Kotiranta H., Larsson K.-H.: Sistotrema luteoviride sp. nov. (Cantharellales, Basidiomycota) from Finland. Acta Mycol. 48(2): 219-225, 2013.

A new Sistotrema species from Northern Finland, S. luteoviride is described and illustrated. The two hitherto known collections derive from Finnish Lapland and both grew on corticated Juniperus communis. The spores are very similar to those of $S$. citriforme, which however is a simple septate species and differs clearly by its ITS sequence.

Key words: Cantharellales, Juniperus communis, Lapland

\section{INTRODUCTION}

Sistotrema Fr. is a comparatively large genus (Index Fungorum 2013) typified by the stipitate species $S$. confluens Fr. Despite the morphology of the type, all other species presently referred to Sistotrema have effused basidiocarps with a smooth, hydnoid or poroid hymenophore. The type species together with a few poroid or hydnoid species probably all have an ectomycorrhizal habit (Nilsson et al. 2006; Münzenberger et al. 2012) while the majority of species seem to be saprophytes. According to Nilsson et al. (2006) the genus is non-monophyletic, and most likely the species outside the core group around the type must be distributed over several genera (Larsson 2007).

During a survey of corticioid species dwelling on Juniperus communis L. in Estonia (Sell, Kotiranta 2011) and Finland, two collections of an unknown species with morphological similarities to Sistotrema citriforme (M.P. Christ.) K.H. Larss. $\&$ Hjortstam were discovered in Finnish Lapland. Molecular phylogenetic analyses confirmed its affinity to Sistotrema and its close relationship to S. citriforme. The species is here characterized and described based on morphological and molecular information. 


\section{MATERIALS AND METHODS}

Thirty spores per specimen were measured in Cotton Blue (CB) or Melzer's reagent (IKI). CB+ means that the walls of the cells are stained by Cotton Blue and CB-, that they are not stained, and IKI- that there is no reaction to Melzer's reagent.

The following abbreviations are used: $L^{*}=$ mean spore length, $W^{*}=$ mean spore width, $Q=$ range of the variation in $\mathrm{L} / \mathrm{W}$ ratio, $Q^{*}=$ quotient of the mean spore length $(L / W)$. None of the measurements derive from a spore print.

Biological province of the collecting site in Finland is indicated according to the Finnish national uniform grid system $\left(27^{\circ} \mathrm{E}\right)$, as applied to biological material by Heikinheimo and Raatikainen (1981). Nine sequences from the nuclear ribosomal ITS and LSU regions are newly published for this study. Data on vouchers and on sequences downloaded from GenBank and included in phylogenetic analyses are provided in Table 1. DNA was extracted from dried specimens (Tab. 1) using DNeasy plant mini kit (Qiagen), following manufacturer's recommendations. PCR reactions were carried out using Ready-To-Go ${ }^{\mathrm{TM}}$ PCR beads (Amersham Pharmacia Biotech). Primers used to amplify the complete ITS region and the $5^{\prime}$ end of the LSU region were ITS1F and ITS4B (Gardes, Bruns 1993), and LR0R and LR7 (Hopple, Vilgalys 1999) respectively. Amplified products were purified using Qiaquick spin columns (Qiagen). Primers used for sequencing were ITS3, ITS4 (White et al. 1990), LR5, LR3R (Hopple, Vilgalys 1999), and CTB6 (http://plantbio.berkeley.edu/bruns/). Sequencing was done by Macrogen (South Korea). Sequences were edited and assembled using Sequencher 3.1 (Gene Codes, Ann Arbor).

Table 1

Species and specimens included in the phylogenetic analysis

\begin{tabular}{|l|c|c|c|c|}
\hline \multicolumn{1}{|c|}{ Species } & Origin & Coll. nr & Herb. & Genb. nr \\
\hline Clavulina cinerea & & & & \\
\hline C. cristata & Finland & K-H Larsson 11694 & GB & EU118616 \\
\hline Membranomyces spurius & Finland & E Larsson 6/00 & GB & \\
\hline Protodontia piceicola & Sweden & K Hjortstam 19169 & GB & \\
\hline Sistotrema brinkmannii & Sweden & K-H Larsson 11803 & GB & DQ873660 \\
\hline S. citriforme & Sweden & K-H Larsson 14078 & GB & \\
\hline S. confluens & K-H Larsson 15898 & GB & \\
\hline S. coroniferum & Sweden & B. Nordén & GB & AM259216 \\
\hline S. luteoviride & Finland & Kotiranta 23176 \& & GB & \\
& & Sell & H & \\
\hline S. muscicola & Finland & K-H Larsson 11721 & GB & AJ606040 \\
\hline S. oblongisporum & Sweden & K-H Larsson 14077 & GB & \\
\hline S. pistilliferum & Spain & E Larsson 28/10 & GB & \\
\hline S. raduloides & Finland & L Ryvarden 44004 & GB & \\
\hline
\end{tabular}

A dataset with 12 sequences representing Sistotrema, Membranomyces Jülich, and Clavulina J. Schröt. was compiled. Protodontia piceicola (Bourdot) G.W. Martin was added as outgroup. The dataset had 2378 nucleotide positions when the 5.8 and LSU regions had been manually aligned. ITS1 and 2 were left unaligned and not included in the analysis. The analysed matrix had 1397 characters of which 115 were parsimony informative and 183 variable but uninformative. Maximum parsimony was performed using PAUP* $4.1 \mathrm{~b} 10$ (Swofford). All transformations were 
considered unordered and equally weighted. Gaps were treated as a fifth character. Heuristic searches used 500 random taxon addition replicates and TBR branch swapping with other options using the program's default settings. Relative robustness of clades was estimated through bootstrap analysis using PAUP*. Settings used were 500 bootstrap replicates with 100 random addition sequences per replicate, TBR branch swapping, and otherwise default settings.

\section{RESULTS}

The phylogenetic analysis generated 4 most parsimonious trees, one of which is shown as a phylogram in Figure 3. This tree had a consistency index 0.7137 . The new species clusters with Sistotrema citriforme with high bootstrap support (98\%). They form together with $S$. pistilliferum Hauerslev, Membranomyces spurius (Bourdot) Jülich, and two Clavulina species a moderately supported clade (79\%). The ingroup is not resolved as monophyletic and the paraphyletic nature of Sistotrema is again indicated (Nilsson et al 2006). However, the restricted dataset used in this study was not designed to reveal any new information regarding the phylogeny of Sistotrema.

The ITS sequences of Sistotrema citriforme and S. luteoviride described below differ by $70-73 \%$ depending on alignment method and including the conservative $5.8 \mathrm{~S}$ gene.

A BLAST search in GenBank with the ITS2 sequence from Sistotrema luteoviride recovered three sequences with $100 \%$ similarity. Two of them were generated from root-tips of Salix reticulata L. in an alpine cliff ecosystem in North Sweden (Ryberg et al. 2009; GenBank accession numbers FM202801, FM203027). The third sequence was recovered from roots of evergreen Quercus laurina Humb. \& Bonpl. in a tropical cloud forest in Mexico (Morris et al. 2009; GenBank accession number FJ196906).

Sistotrema luteoviride Kotir. \& K.H. Larss., sp. nov.

Figs 1,2

MycoBank no. MB 804722

Fructificatio resupinata, adherens, hymenophorum laeve, reticulato - porosum, luteoviride, systema hypharum monomiticum, hyphis fibulatis, cystidia desunt; basidia urniformia vel subcylindracea, (19-)21-36(-40) × 6-8(-9) $\mu \mathrm{m}, 6(5-7)$ sterigmatibus, sporae laevae, late ellipsoideae vel pyriformes, (4.6-)5-6 × (3.6-)4-4.8(-5) $\mu \mathrm{m}$.

Holotype: Finland. Inarin Lappi (Lapponia inarensis): Utsjoki, Kevo strict nat. reserve, Keneskoski, mixed river-side forest with Betula pubescens ssp. czerepanovii (Orlova) Hämet-Ahti, Salix spp., and Juniperus communis L., on fairly hard, corticated Juniperus, diameter $3 \mathrm{~cm}$; also Tomentella sp., $69^{\circ} 43^{\prime} \mathrm{N}, 27^{\circ} 02^{\prime} \mathrm{E}$, alt $84 \mathrm{~m}$ a.s.l. (Grid 27E:7740:(3)500), 23 Sept. 2009, leg. H. Kotiranta 23176 \& Sell (H).

Etymology: the epithet luteoviride refers to the colour of the fruit body, which is yellow with a greenish hue.

Basidiocarp resupinate, relatively thick and tough, adnate, almost smooth, finely porose - reticulate under the lens, yellow, yellowish or yellowish green, margin distinct clear, or thinning out, not differentiated, without rhizomorphs.

Hyphal system monomitic, hyphae clamped, partly filled with oily contents, in subiculum fairly thin- to relatively thick-walled, $\mathrm{CB}+$, either "normal" long-celled, 3-4 $\mu \mathrm{m}$ in diameter (minority), or short-celled, almost isodiametric, $6-9 \mu \mathrm{m}$ in diam. 


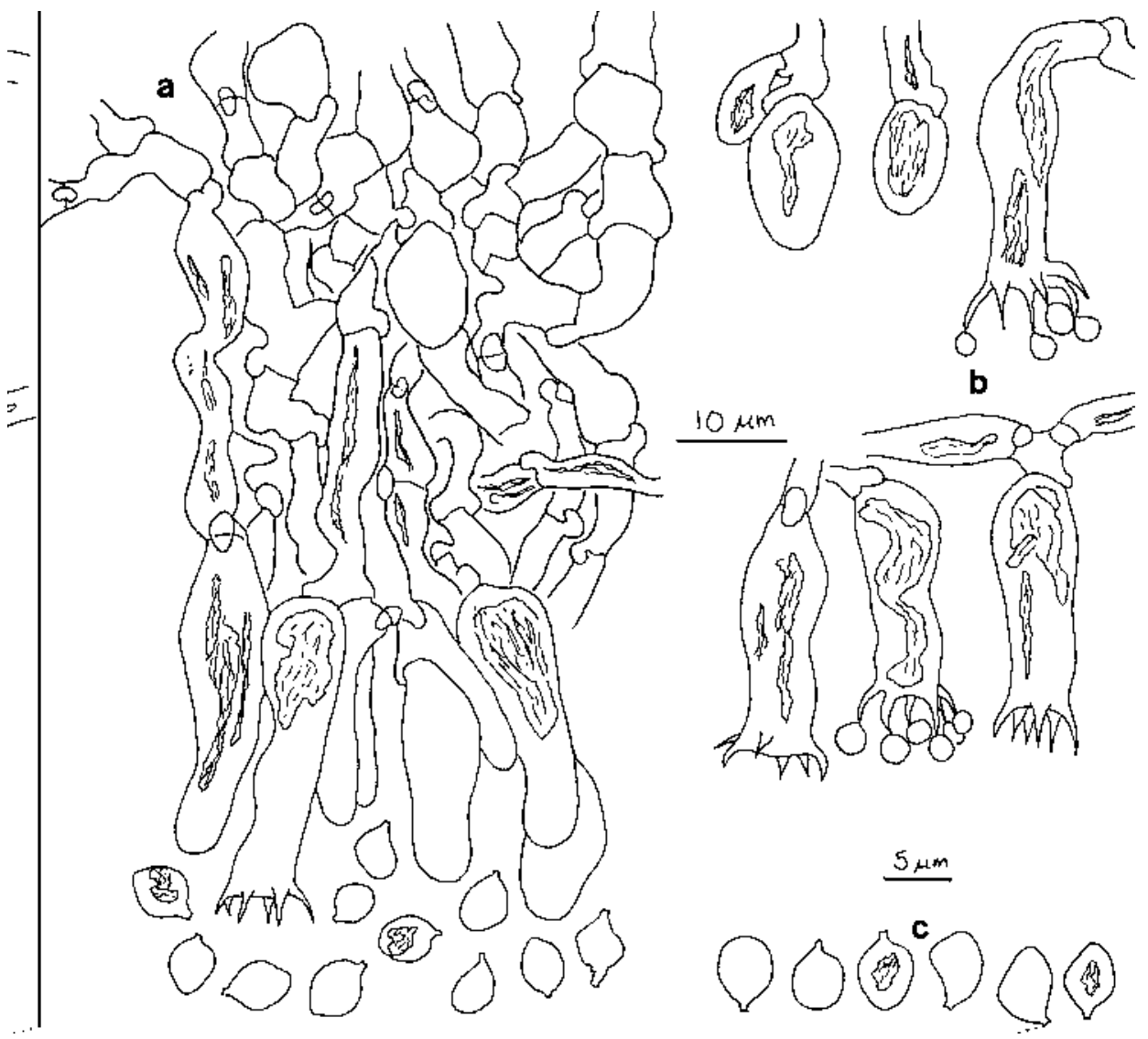

Fig. 1. Sistotrema luteoviride Kotir. \& K.-H. Larss. (H. Kotiranta 23176, type): a - section through basidiocarp showing the hyphal structure, basidia and spores, - b basidia, - c spores.

Subhymenial hyphae thin-walled, (2.5-)3-4(-4.5) um wide. Cystidia none. Basidia urniform or subcylindrical, with oily contents, basally clamped, (19-)21-36(-40) $\times$ $6-8(-9) \mu \mathrm{m}$, with normally $6(5-7)$, up to $7 \mu \mathrm{m}$ long curved sterigmata. Spores at first broadly ellipsoid, when fully ripe pyriform - subangular, sometimes almost biapiculate, (4.7-)5-5.6(-5.8) × 3.6-4.6(-5) $\mu \mathrm{m}, L^{*}=5.2 \mu \mathrm{m}, W^{*}=4.1 \mu \mathrm{m}, Q=1.1-1.5$, $Q^{*}=1.3$ (Kotiranta $23176 \&$ Sell, type), $(4.6-) 5-6 \times 4-4.8(-5) \mu \mathrm{m}, L^{*}=5.3 \mu \mathrm{m}, W^{*}$ $=4.4 \mu \mathrm{m}, Q=1.1-1.5, Q^{*}=1.2$ (Kotiranta 23126 ) often with oily contents, with a prominent, up to $1 \mu \mathrm{m}$ long apiculus, thin-walled, CB-, IKI-.

AdDitional SPECIMEN EXAMINED: Finland. Inarin Lappi (Lapponia inarensis): Utsjoki, Kevo strict nat. reserve, close to the biological station, Pinus sylvestris L. dominated dry heath forest site, on corticated living Juniperus, diameter $4 \mathrm{~cm}$; also $\mathrm{Hy}$ phoderma argillaceum (Bres.) Donk, Tomentella sp., 69 $45^{\prime} \mathrm{N}, 27^{\circ} 00^{\prime} \mathrm{E}$, alt $105 \mathrm{~m}$ a.s.l. (Grid 27²E:77417:(3)5008), 20 Sept. 2009, leg. H. Kotiranta 23126 (H). In the field, the colour of Sistotrema luteoviride resembles that of Leptosporomyces galzinii (Bourdot) Jülich, but is more intensively yellow, and the basidiocarp is not soft and pliable but tough and adnate. In microscope the species are quite different. 


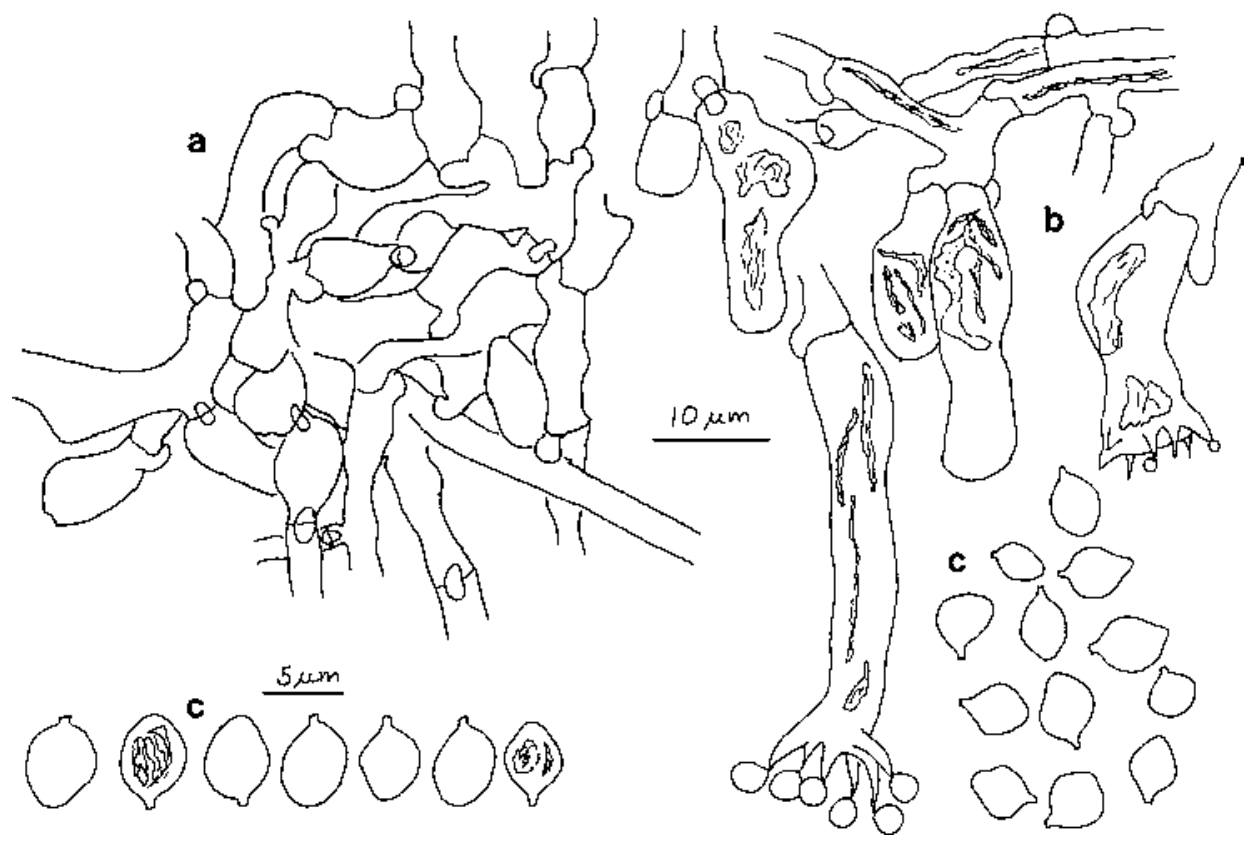

Fig. 2. Sistotrema luteoviride Kotir. \& K.-H. Larss. (H. Kotiranta 23126): a - almost isodiametric hyphae in subiculum, - b basidia at different stages of development, - c spores.

The new species resembles by its spores Sistotrema citriforme (syn. S. subangulisporum K.H. Larss. \& Hjortstam, see Eriksson et al. 1984, p. 1365), but the latter is simple septate and the hyphae are much narrower, without isodiametric, wide cells. Also the basidia are larger in S. luteoviride. Similar spores are also present in S. pistilliferum but the latter species differs by presence of cystidia. All three species have clearly different ribosomal sequences (Fig. 3).

Nilsson et al. (2006) recovered a Clavulina clade that also included Membranomyces delectabile (H.S. Jacks.) Kotir. \& Saaren., a corticioid fungus but with Clavulina-like basidia. Here we included M. spurius, the second species of the genus, with similar result. Tedersoo et al. (2003) identified M. delectabile from root-tips in a mixed forest in Estonia and Clavulina species are generally regarded as forming ectomycorrhiza and most likely all species in the clade are mycorrhizal (Tedersoo et al. 2010). Here we show for the first time that species with a morphology fitting a traditional Sistotrema concept also can occur in the Clavulina clade. The position of $S$. luteoviride, $S$. citriforme, and $S$. pistilliferum among species of Clavulina indicates a mycorrhizal habit, which is also underlined by the environmental sequences that we found in GenBank.

Even if there are hitherto only two specimens of $S$. luteoviride, we believe that it is not an especially rare species in the subarctic areas of the Northern Hemisphere. The habitats, river- or brook-side forests, nutritionally poor Pinus sylvestris dominated forests, and alpine heath vegetation, are very common in the north. The substrate in both collections was a corticated Juniperus communis, but if we believe that the species is a symbiont common juniper is unlikely to be the host. Rather the juniper 


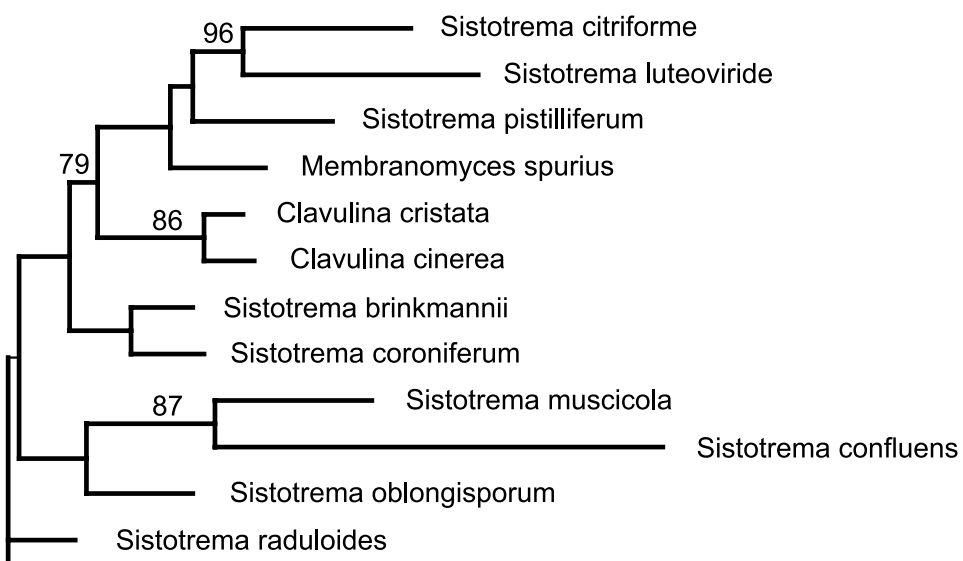

Protodontia piceicola

10

Fig. 3. Phylogram of one of four trees of length 468 from the maximum parsimony analysis. Numbers on branches show all bootstrap values higher than $75 \%$. The scale indicates number of changes along the branches.

bushes happened to offer a suitable substrate where $S$. luteoviride could develop its resupinate, effused basidiocarps.

Acknowledgements. We are grateful to Teuvo Ahti (Helsinki) who helped us with the Latin diagnosis. Ellen Larsson, University of Gothenburg, is acknowledged for her proficiency in producing the DNA sequences. The senior author thanks Anton Schiryaev (Ekaterinburg) and Indrek Sell (Tartu) for the nice companionship during the collection trip in Lapland. Also the staff of Kevo Biological Station is warmly thanked for the hospitality during our stay at the station.

\section{REFERENCES}

Eriksson J., Hjortstam K., Ryvarden L. 1984. The Corticiaceae of North Europe. Schizopora - Suillosporium. 7: 1281-1449.

Gardes M., Bruns T.D. 1993. ITS primers with enhanced specificity for basidiomycetes--application to the identification of mycorrhizae and rusts. Mol. Ecol. 2 (2):113-118. http://www.ncbi.nlm.nih.gov/ pubmed/8180733

Heikinheimo O., Raatikainen M. 1981. Ruutukoordinaattien ja paikannimien käyttö Suomessa [Grid references and names of localities in the recording of biological finds in Finland]. Notul. Entomol. 61: 133-154, [In Finnish].

Hopple J.S.Jr., Vilgalys R. 1999. Phylogenetic relationships in the mushroom genus Coprinus and dark-spored allies based on sequence data from the nuclear gene coding for the large ribosomal subunit RNA: divergent domains, outgroups, and monophyly. Molecular Phylogenetics and Evolution 13 (1):1-19.

Index Fungorum. 2013. Sistotrema. www.indexfungorum.org/names/Names.asp, 15.3.2013.

Larsson K.-H. 2007. Re-thinking the classification of corticioid fungi. Mycological Research 111: 1040-1063.

Morris M.H., Pérez-Pérez M.A., Smith M.E., Bledsoe C.S. 2009. Influence of host species on ectomycorrhizal communities associated with two co-occurring oaks (Quercus spp.) in a tropical cloud forest. FEMS Microbiology Ecology 69: 274-287.

Münzenberger B., Schneider B., Nilsson R.H., Bubner B., Larsson K.-H., Hüttl R.F. 2012. Morphology, anatomy, and molecular studies of the ectomycorrhiza formed axenically by the fungus Sistotrema sp. (Basidiomycota). Mycological Progress 11: 817-826. 
Nilsson R.H., Larsson K.-H., Larsson E., Kõljalg U. 2006. Fruiting body-guided molecular identification of root-tip mantle mycelia provides strong indications of ectomycorrhizal associations in two species of Sistotrema (Basidiomycota). Mycological Research 110: 1426-1432.

Ryberg M., Larsson E., Molau U. 2009. Ectomycorrhizal diversity on Dryas octopetala and Salix reticulata in an alpine cliff ecosystem. Arctic, Antarctic, and Alpine Research 41: 506-514. http://dx.doi.org/1 $0.1657 \% 2 \mathrm{~F} 1938-4246-41.4 .506$

Sell I., Kotiranta H. 2011. Diversity and distribution of Aphyllophoroid fungi growing on Common Juniper (Juniperus communis L.) in Estonia. Folia Cryptogamica Estonica 48: 73-84.

Tedersoo L., Kõljalg U., Hallenberg N., Larsson K.-H. 2003. Fine scale distribution of ectomycorrhizal fungi and roots across substrate layers including coarse woody debris in a mixed forest. New Phytologist 159: 153-165. http://dx.doi.org/10.1046\%2Fj.1469-8137.2003.00792.x

Tedersoo L., May T.W., Smith M.E. 2010. Ectomycorrhizal lifestyle in fungi: global diversity, distribution, and evolution of phylogenetic lineages. Mycorrhiza 20:217-263. http://dx.doi.org/10.1007\%2Fs00572009-0274-x 